\title{
Use of Information and Communication Technologies (ICTs) by University Freshmen: With Special Reference to the University of Moratuwa
}

Kumara, A. D. B. ${ }^{1}$

\begin{abstract}
New coming students for universities are fundamentally different than in the past, because they have been spending their entire lives surrounded by and using ICTs. These students belong to the net generation and always looking for ICTs in each and every activity of their life. However, it is questioned whether all students are in the same level since they should be very fluent with ICTs to move in this $21^{\text {st }}$ century confidently. This study is an attempt made to investigate the level of using ICTs by new coming undergraduates to the University of Moratuwa by examining the frequency of using ICT tools, self rated skill levels and finally their perceptions of the impact of ICT on academic experiences in the university. Twenty two (22) different ICT related activities under 4 main skill domains; basic computer usage, computer applications, Internet/E-mail use and use of technologies for research/academic activities were used for the study. The study is compiled with data from questionnaires of 338 first year students in three faculties; Architecture, Engineering and Information Technology. The study reveals that there is a rapid trend towards a higher ICT usage of university freshmen as digital natives. Majority of the first year students more frequently use computer applications such as word processing, Spreadsheets and Presentation packages. and they have rated themselves as highly skilled in computer applications. The male students reported to be in front in terms of usage of ICTs and level of computer literacy skills than female students. Freshmen from urban communities always believe that they are more skilful in this aspect. Architecture students are somewhat below than others in using ICTs as well as the level of ICT skills. Majority of freshmen believe that using ICTs may help them to improve their learning in the university and they are willing to use ICTs to find information on academic purposes. Recommendations have been made to enhance ICT facilities and programs for freshmen at university.
\end{abstract}

Keywords: ICT, Undergraduates, University of Moratuwa, Sri Lanka

\section{Introduction}

For today's Sri Lankan undergraduates, ICTs play an integral role in their everyday life. They are frequently using various novel technologies for different purposes. In many times they adopt new technologies when they perceive the benefits and costs to align. They report

\footnotetext{
${ }^{I}$ Senior Assistant Librarian, University of Moratuwa, Sri Lanka.Email: buddhin@lib.mrt.ac.lk
} 
wide range of preferences on various novel ICTs, and use skills in the academic context. It is better to facilitate these requirements in the academia to build up a technology savvy generation.

As Prensky argued in his paper in 2001 new group of students coming in to was fundamentally different from any that educators had been before. This new generation of students is digital natives. Digital natives had spent their entire lives surrounded by and using computers, video games, digital music players, video cams, cell phones, and all other toys and tools of the digital age (Prensky, 2001).

Most of the students arriving at university fall into "digital natives" in the sense that they have grown up with computers, software applications, Internet access, and communication tools. Recent surveys show that word processing, for instance is native to these students in the sense that most of them report having learned it at home with family support (Hoffman \& Vance, 2005).

Incoming freshmen are increasingly expected to have a grasp of basic ICT skills before they ever set foot in a college classroom. Lack of basic ICT skills may retard the students' ability in performing fundamental tasks required at the university level. Therefore it is worth to test their ICT literacy levels to face the challenges of the new world successfully.

\section{Significance of the Study}

ICTs can have a dramatic impact on achieving specific social and economic development goals and also can play a key role in broader national development strategies (Digital opportunity initiative, 2001). Therefore, ICTs have successfully been implemented in various sectors such as industrial, social, education etc. Even though Sri Lanka is a country with a small geographical span, the power of ICT plays a major role in almost all those fields. As such, Sri Lankan higher education is becoming increasingly technology-intensive (Aturupane, 2008). Therefore, there is an increasingly urgent need for university students to have stronger ICT literacy skills and study like this is very important because it can; 
- Provide information on the technology behaviors, preferences and attitudes of undergraduates.

- provide information to university administrators that will help them to implement university technology environment for students, and

- Inform practices of teaching faculty and librarians to develop their curricula, resources and services in rich and meaningful ways.

The assessment of ICT literacy of Millennial Generation is very vital for the total university system for the enhancement of their activities in making quality graduate output to gain a high demand all over the world. Also this may be an important avenue for other researchers to conduct studies in various contexts.

\section{Statement of the Problem}

The use of ICT is pervasive throughout the university curriculum. The University of Colombo, School of Computing (UCSC) had conducted a study in 2009 to measure the IT proficiency of undergraduates in higher education institutions in Sri Lanka. They have carried out IT proficiency test to evaluate the IT knowledge and skill of undergraduates following IRQUE supported programs by the UCSC. The study emphasized that although the majority of students have the minimum required knowledge and skills to use a computer, they do not possess the professional level competency required in the job market. So that the first year students who arrive deficient in these skills are ill-prepared to succeed in today's academic environment. Given that the modern workplace requires ICT-literate knowledge workers, it is imperative that students attain the skills required to succeed. Therefore a study on ICT literacy for the university Millennial Generation (MG) is a must in this technological era.

\section{Objectives of the Study}

General Objective

To study the level of using ICTs by first year students 
Specific Objectives

1. To determine the frequency of using ICTs by first year students at the UoM.

2. To assess student self perceived skills of using technologies.

3. To examine their perceptions about the impact of technology use on their studies at the university.

\section{Research Design}

The research was designed selecting a well suited method to examine the level of using ICTs by the students of the University of Moratuwa. Twenty two (22) different ICT related activities under 4 main skill domains; basic computer usage (computer hardware and software, file management, etc.), computer applications (word processing, spreadsheets, etc.), Internet/E-mail use and use of technologies for research/academic activities (Internet browsers, use of wikis, blogs, etc.) were adapted from Madigan (2007) for the study.

\section{Research Methods}

To achieve the objectives of the study, the researcher adapted the survey research strategy. Data collection methods are followed by the selected research strategy and therefore structured questionnaire was used as the data collecting methods based on the survey strategy.

\section{Population}

The total number of students registered during the 2011/2012 Academic year has been selected as the population of the study. Distribution of the population by faculties is presented in Table 1. 
Table 1: Distribution of the population by faculty

\begin{tabular}{|c|c|c|c|}
\hline \multicolumn{3}{|c|}{ Faculty } & Total \\
\hline Architecture & Engineering & IT & \\
\hline 305 & 842 & 208 & 1355 \\
\hline
\end{tabular}

Source: Department of Examination, University of Moratuwa

\section{Sample}

Stratified random sampling technique was used for the study, in order to present all the categories of the population. 'Faculty' was identified as the criteria for the stratification. The sample was selected to represent each stratum proportionately. $25 \%$ of each stratum was taken into account. The $25 \%$ elements with decimal places in any strata were counted to the next digit. The selected stratified random sample is presented in the Table 2 .

Table 2: Distribution of the sample by faculty

\begin{tabular}{|c|c|c|c|c|}
\hline & \multicolumn{3}{|c|}{ Faculty } & \multirow{2}{*}{ Total } \\
\hline & Architecture & Engineering & IT & \\
\hline Population & 305 & 842 & 208 & 1355 \\
\hline Sample & 76 & 211 & 52 & 339 \\
\hline
\end{tabular}

\section{Results of the Study}

Analysis was conducted to achieve the level of using ICTs by first year students in the University of Moratuwa using SPSS 16.0. Results were presented in percentages, tables and graphs.

Out of 339 questionnaires distributed, 338 were received at a rate of $99.71 \%$. Except the IT faculty, the response rate was $100 \%$. Therefore, the overall response rate is satisfactory. Table 3 summarizes the distribution of respondents by faculty, age, gender, ethnicity and the community. 
Table 3: Distribution of the respondents

\begin{tabular}{|l|l|l|l|l|l|}
\hline \multicolumn{2}{|c|}{} & \multicolumn{3}{|c|}{ Faculty } & \multirow{2}{*}{ Total } \\
\cline { 3 - 6 } \multicolumn{2}{c|}{} & Archi. & IT & Eng. & \\
\hline \multirow{2}{*}{ Age: } & Mean & 20.71 & 20.62 & 20.47 & 20.55 \\
\cline { 2 - 5 } & Std.Deviation & 0.72 & 0.69 & 0.71 & 0.71 \\
\hline \multirow{3}{*}{ Gender (\%): } & Male & 63.2 & 62.7 & 79.6 & 73.4 \\
\cline { 2 - 5 } & Female & 36.8 & 37.3 & 20.4 & 26.6 \\
\hline \multirow{4}{*}{ Ethnicity (\%): } & Sinhala & 81.6 & 70.6 & 88.5 & 84.3 \\
\cline { 2 - 5 } & Tamil & 13.2 & 21.6 & 10.0 & 12.4 \\
\cline { 2 - 5 } & Muslim/Moor & 5.3 & 7.8 & 0.5 & 2.7 \\
\cline { 2 - 5 } & Other & 0 & 0 & 1.0 & 0.6 \\
\hline \multirow{3}{*}{ Community (\%): } & Rural & 25.3 & 21.6 & 23.7 & 23.7 \\
\cline { 2 - 5 } & Suburban & 40.0 & 43.1 & 48.3 & 45.7 \\
\cline { 2 - 5 } & Urban & 34.7 & 35.3 & 28.0 & 30.6 \\
\hline
\end{tabular}

Table 3 shows that the most of the respondents are male students' (73.4\%). Also the largest percentage of respondents was Sinhala (84.3\%) and most of respondents are 21 and 22 years old. Further, it shows that most of the respondents are from suburban areas and the relevant percentage is $45.7 \%$.

Respondents were asked whether they have followed any computer courses before entering the university and Figure 1 demonstrates the distribution of respondents as they followed introductory computer courses among faculties.

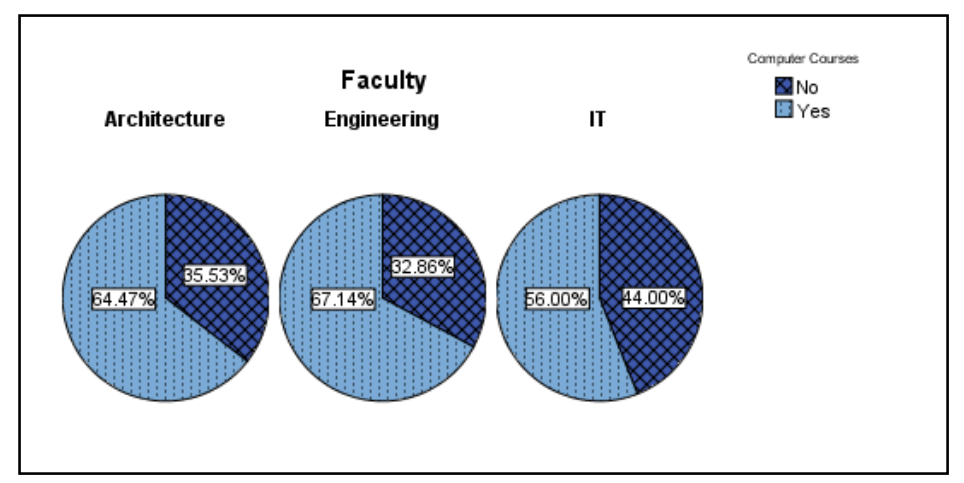

Figure 1: Distribution of respondents faculties vs following introductory computer courses 
Figure clearly shows that more than $50 \%$ of the students in each faculty have followed any introductory computer course. The relevant percentages are $64.47 \%, 57.14 \%$ and $56 \%$ for Architecture, Engineering and IT faculties respectively.

\section{Frequency of Using ICTs}

Respondents were asked how often on average they have used technologies under different 22 ICT related activities under 4 main skill domains; basic computer usage, computer applications, use of Internet/E-mail and use of ICTs for research/academic activities.

Table 4 summarizes the usage frequencies of the selected ICT related activities under 4 main domains.

Table 4: Usage frequencies of the ICT related activities

\begin{tabular}{|c|c|c|c|c|c|c|c|c|c|c|}
\hline \multicolumn{2}{|c|}{$\begin{array}{l}\stackrel{\Xi}{\Xi} \\
\stackrel{\Xi}{0}\end{array}$} & Activity & $\stackrel{\lambda}{\bar{\Xi}}$ & 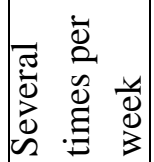 & $\begin{array}{l}\frac{\lambda}{8} \\
\frac{\pi}{3} \\
\frac{3}{3}\end{array}$ & 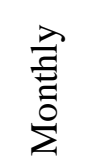 & 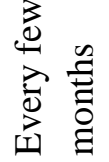 & 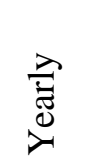 & $\stackrel{\frac{\pi}{0}}{0}$ & 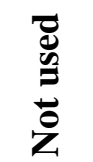 \\
\hline 1 & \multirow{5}{*}{ 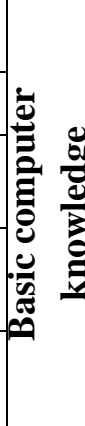 } & Computer hardware & 7.5 & 11.4 & 12.3 & 23.7 & 31.6 & 13.6 & 73.3 & 26.7 \\
\hline 2 & & Computer software & 20.6 & 30.1 & 17.4 & 13.8 & 13.1 & 5.0 & 88.4 & 11.6 \\
\hline 3 & & File management & 36.7 & 28.4 & 18.2 & 8.0 & 5.7 & 3.0 & 82.8 & 17.2 \\
\hline 4 & & $\begin{array}{l}\text { CD burning including } \\
\text { data and music files }\end{array}$ & 7.2 & 22.1 & 25.0 & 27.5 & 15.6 & 2.5 & 85.7 & 14.3 \\
\hline 5 & & $\begin{array}{l}\text { File transfer } \\
\text { applications }\end{array}$ & 10.9 & 18.1 & 23.8 & 23.8 & 18.1 & 5.2 & 59.9 & 40.1 \\
\hline 6 & \multirow{3}{*}{ 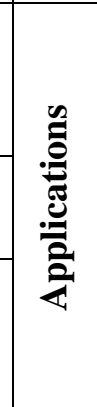 } & $\begin{array}{l}\text { Word processing } \\
\text { such as Microsoft } \\
\text { Word }\end{array}$ & 11.9 & 24.9 & 19.6 & 26.3 & 12.6 & 4.6 & 92.2 & 7.8 \\
\hline 7 & & $\begin{array}{l}\text { Spreadsheets such as } \\
\text { Microsoft Excel }\end{array}$ & 3.7 & 21.1 & 17.8 & 25.9 & 21.1 & 10.4 & 85.7 & 14.3 \\
\hline 8 & & $\begin{array}{l}\text { Database handling } \\
\text { such as Microsoft } \\
\text { Access }\end{array}$ & 2.7 & 17.1 & 12.3 & 16. & 29.4 & 22.5 & 59.6 & 40.4 \\
\hline
\end{tabular}




\begin{tabular}{|c|c|c|c|c|c|c|c|c|c|c|}
\hline 9 & & $\begin{array}{l}\text { Presentation } \\
\text { packages such as } \\
\text { Microsoft } \\
\text { PowerPoint }\end{array}$ & 3.0 & 16.0 & 14.9 & 31.6 & 24.9 & 9.7 & 87.6 & 12.4 \\
\hline 10 & & Web designing & 3.8 & 16.0 & 14.5 & 14.5 & 25.2 & 26.0 & 41.2 & 58.8 \\
\hline 11 & & Multimedia editing & 4.8 & 1.0 & 14.4 & 25.1 & 21.6 & 16.2 & 52.4 & 47.6 \\
\hline 12 & & $\begin{array}{l}\text { Discipline/ Subject } \\
\text { specific technologies }\end{array}$ & 3.2 & 10.6 & 8.5 & 21.3 & 34.0 & 22.3 & 29.2 & 70.8 \\
\hline 13 & \multirow{7}{*}{ 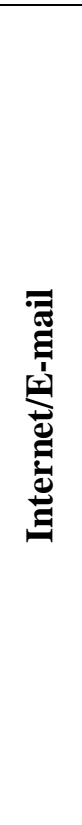 } & $\begin{array}{l}\text { Internet browsers } \\
\text { such as Explore, } \\
\text { Mozilla etc. }\end{array}$ & 48.1 & 26.3 & 99 & 8.2 & 5.5 & 2.0 & 92.4 & 7.6 \\
\hline 14 & & $\begin{array}{l}\text { Emails including } \\
\text { attachments, global } \\
\text { emails and save } \\
\text { emails }\end{array}$ & 31.2 & 28.8 & 21.2 & 12.2 & 5.6 & 1.0 & 90.9 & 9.1 \\
\hline 15 & & $\begin{array}{l}\text { Instant and text } \\
\text { messaging }\end{array}$ & 26.9 & 27.9 & 15.7 & 17.3 & 8.1 & 4.1 & 68.3 & 31.7 \\
\hline 16 & & $\begin{array}{l}\text { Use of Wikis, Blogs, } \\
\text { Video websites }\end{array}$ & 26.7 & 28.7 & 20.2 & 14.2 & 8.5 & 1.6 & 92.9 & 7.1 \\
\hline 17 & & Online games & 16.8 & 17.3 & 15.6 & 21.2 & 16.8 & 12.3 & 61.5 & 38.5 \\
\hline 18 & & $\begin{array}{l}\text { Social Networking } \\
\text { websites }\end{array}$ & 56.1 & 20.8 & 16.0 & 3.3 & 2.6 & 1.1 & 92.7 & 7.3 \\
\hline 19 & & $\begin{array}{l}\text { Use of WWW for } \\
\text { other services }\end{array}$ & 11.8 & 15.1 & 8.6 & 30.1 & 21.5 & 12.9 & 34.1 & 65.9 \\
\hline 20 & \multirow{3}{*}{ 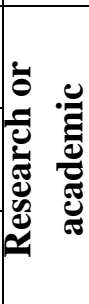 } & $\begin{array}{l}\text { Web searching for } \\
\text { information }\end{array}$ & 58.2 & 23.1 & 5.5 & 8.8 & 3.3 & 1.1 & 90.9 & 9.1 \\
\hline 21 & & $\begin{array}{l}\text { Use of university } \\
\text { website }\end{array}$ & 12.7 & 26.8 & 23.6 & 17.8 & 14.0 & 5.1 & 48.8 & 51.2 \\
\hline 22 & & $\begin{array}{l}\text { Use of university } \\
\text { Library Website }\end{array}$ & 6.7 & 27.6 & 29.5 & 18.1 & 14.3 & 3.8 & 61.5 & 38.5 \\
\hline
\end{tabular}

As shown in Table 4, more than $90 \%$ of the respondents have used word processing (92.2\%), Internet browsers such as Explore (92.4\%), use of Wikis, Blogs, Video websites (92.9\%), Social Networking websites (92.7\%), Web searching for information (90.9\%), Emails (90.9\%). 
Further, the table clearly shows that although the majority of the students use university website, usage of the library website is low when consider with others. However considerable percentage of students $(90.9 \%)$ used Web searching for information using databases, catalogues, search engines etc.

Means, standard deviations and One-Way ANOVA F-values of frequency levels are shown for subject streams in each of the basic computer activity in Table 5.

Table 5: Basic computer skill differences among subject streams

\begin{tabular}{|l|l|l|l|l|l|l|l|l|}
\hline \multirow{2}{*}{ Activity } & \multicolumn{2}{|c|}{ Architecture } & \multicolumn{2}{c|}{ Engineering } & \multicolumn{2}{c|}{ IT } & \multirow{2}{*}{ F-value } & \multirow{2}{*}{ Sig. } \\
\cline { 2 - 9 } & Mean & StDev & Mean & StDev & Mean & StDev & & 0.282 \\
\hline $\begin{array}{l}\text { Computer } \\
\text { hardware }\end{array}$ & 2.18 & 0.912 & 2.38 & 0.955 & $\mathbf{2 . 4 9}$ & 0.935 & 1.272 & 0.062 \\
\hline $\begin{array}{l}\text { Computer } \\
\text { software }\end{array}$ & $\mathbf{2 . 5 4}$ & 0.884 & 2.77 & 0.916 & 3.15 & 0.792 & 5.462 & $\mathbf{0 . 0 0 5}$ \\
\hline $\begin{array}{l}\text { File } \\
\text { management }\end{array}$ & $\mathbf{3 . 1 5}$ & 1.106 & 3.2 & 1.023 & $\mathbf{3 . 6 6}$ & 1.087 & 2.814 & 0.062 \\
\hline CD burning & $\mathbf{3 . 0 6}$ & 1.227 & 3.29 & 1.047 & $\mathbf{3 . 4 1}$ & 1.013 & 1.222 & 0.296 \\
\hline File transfer & 2.86 & 0.970 & $\mathbf{2 . 8 9}$ & 1.076 & $\mathbf{2 . 9 7}$ & 1.150 & 0.120 & 0.887 \\
\hline
\end{tabular}

As highlighted in the Table 5, there are significant differences among subject streams in computer software skills such as operating systems, installing and removing programs etc. It clearly shows that IT students' perceived skills are higher than other students for above activities. Further, the usage frequencies of Internet/E-mail related activities are higher for the urban students (p-value is 0.000) and as well as IT students.

Results clearly demonstrate that the most of the ICT usage frequencies were comparatively higher for IT students and students from urban communities than others.

\section{Perceived ICT Skills}

Respondents were asked themselves to rate the skill level of different 22 ICT related activities under 4 main skill domains. Five Likert scale was used from 1-not very skilled to 5-expert. Percentages of the respondents' are summarized in Table 6. 
Table 6: Percentages of respondents according to the skill levels of ICT

\begin{tabular}{|c|c|c|c|c|c|c|c|}
\hline & & Activity & 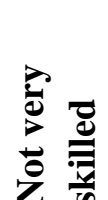 & 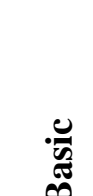 & 离 & 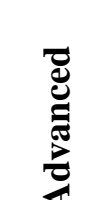 & 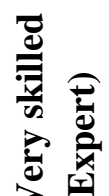 \\
\hline 1 & & $\begin{array}{l}\text { Computer } \\
\text { hardware }\end{array}$ & 20.2 & 35.0 & 34.6 & 9.1 & 1.2 \\
\hline 2 & $\frac{8}{8}$ & $\begin{array}{l}\text { Computer } \\
\text { software }\end{array}$ & 6.0 & 33.5 & 40.5 & 16.9 & 3.2 \\
\hline 3 & 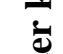 & File management & 4.2 & 16.0 & 37.6 & 26.2 & 16.0 \\
\hline 4 & 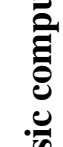 & $\begin{array}{l}\text { CD burning } \\
\text { including data and } \\
\text { music files }\end{array}$ & 5.3 & 18.4 & 33.1 & 30.5 & 12.8 \\
\hline 5 & 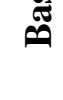 & $\begin{array}{l}\text { File transfer } \\
\text { applications }\end{array}$ & 8.9 & 26.3 & 40.0 & 15.3 & 9.5 \\
\hline 6 & & $\begin{array}{l}\text { Word processing } \\
\text { such as Microsoft } \\
\text { Word }\end{array}$ & 3.1 & 22.0 & 41.0 & 25.8 & 8.1 \\
\hline 7 & & $\begin{array}{l}\text { Spreadsheets such } \\
\text { as Microsoft Excel }\end{array}$ & 8.0 & 29.8 & 38.5 & 20.0 & 3.6 \\
\hline 8 & & $\begin{array}{l}\text { Database handling } \\
\text { such as Microsoft } \\
\text { Access }\end{array}$ & 19.4 & 35.7 & 30.1 & 10.7 & 3.1 \\
\hline 9 & 苞 & $\begin{array}{l}\text { Presentation } \\
\text { packages such as } \\
\text { Microsoft } \\
\text { PowerPoint }\end{array}$ & 7.7 & 22.9 & 40.5 & 23.9 & 5.0 \\
\hline 10 & & Web designing & 21.7 & 31.9 & 31.9 & 10.9 & 3.6 \\
\hline 11 & & $\begin{array}{l}\text { Multimedia } \\
\text { editing }\end{array}$ & 18.7 & 31.0 & 33.3 & 13.5 & 3.5 \\
\hline 12 & & $\begin{array}{l}\text { Discipline/ Subject } \\
\text { specific } \\
\text { technologies }\end{array}$ & 22.4 & 38.8 & 28.6 & 8.2 & 2.0 \\
\hline
\end{tabular}




\begin{tabular}{|c|c|c|c|c|c|c|c|}
\hline 13 & \multirow{7}{*}{ 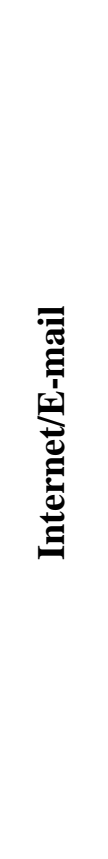 } & $\begin{array}{l}\text { Internet browsers } \\
\text { such as Explore, } \\
\text { Mozilla etc. }\end{array}$ & 5.8 & 19.1 & 32.1 & 23.2 & 19.8 \\
\hline 14 & & $\begin{array}{l}\text { Emails including } \\
\text { attachments, } \\
\text { global emails and } \\
\text { save emails }\end{array}$ & 2.4 & 23.3 & 38.3 & 20.2 & 15.7 \\
\hline 15 & & $\begin{array}{l}\text { Instant and text } \\
\text { messaging }\end{array}$ & 7.8 & 20.2 & 36.8 & 22.3 & 13.0 \\
\hline 16 & & $\begin{array}{l}\text { Use of Wikis, } \\
\text { Blogs, Video } \\
\text { websites }\end{array}$ & 4.7 & 24.5 & 36.0 & 26.5 & 8.3 \\
\hline 17 & & Online games & 8.8 & 23.4 & 36.3 & 18.7 & 12.9 \\
\hline 18 & & $\begin{array}{l}\text { Social Networking } \\
\text { websites }\end{array}$ & 2.7 & 15.9 & 31.0 & 27.5 & 22.9 \\
\hline 19 & & $\begin{array}{l}\text { Use of WWW for } \\
\text { other services }\end{array}$ & 15.6 & 26.7 & 32.2 & 20.0 & 5.6 \\
\hline 20 & \multirow{3}{*}{ 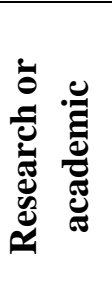 } & $\begin{array}{l}\text { Web searching for } \\
\text { information }\end{array}$ & 4.2 & 23.4 & 38.8 & 18.9 & 14.7 \\
\hline 21 & & $\begin{array}{l}\text { Use of university } \\
\text { website }\end{array}$ & 6.0 & 31.1 & 39.7 & 18.5 & 4.6 \\
\hline 22 & & $\begin{array}{l}\text { Use of university } \\
\text { Library Website }\end{array}$ & 6.9 & 28.7 & 40.6 & 21.8 & 2.0 \\
\hline
\end{tabular}

The largest percentage of respondents has rated themselves as they are very skilful in using Social Networking websites. The related percentage is $22.9 \%$. According to the ANOVA performed, male students rated themselves as more skilful than female students and urban students rated themselves as more skilful than other students on using Social Networking websites such as Face Book. Further, the perceived skills on using Social Networking sites have a significant difference with the completion/not completion introductory computer course/s.

Respondents have rated that they are not much skilful on discipline/ subject specific technologies (percentage is $22.4 \%$ ). This may be because during the first semester of the 
first year most students have not aware discipline/subject specific technologies. The p-value of the test is 0.001 . An interesting feature is that the rated computer software skills of IT students are higher than that of others ( $\mathrm{p}$-value $=0.005$ ).

\section{Perceptions of the Impact of ICT on Academic Experience}

Perceptions of the respondents on the impact of ICTs on academic experience were examined under six scenarios (Learning, course activities, results, skills, academic quality, and communication) by reviewing the past literature. Five Likert scale was used. Distribution of the respondents as their perceptions of using ICTs on academic experiences is summarized in Figure 2.

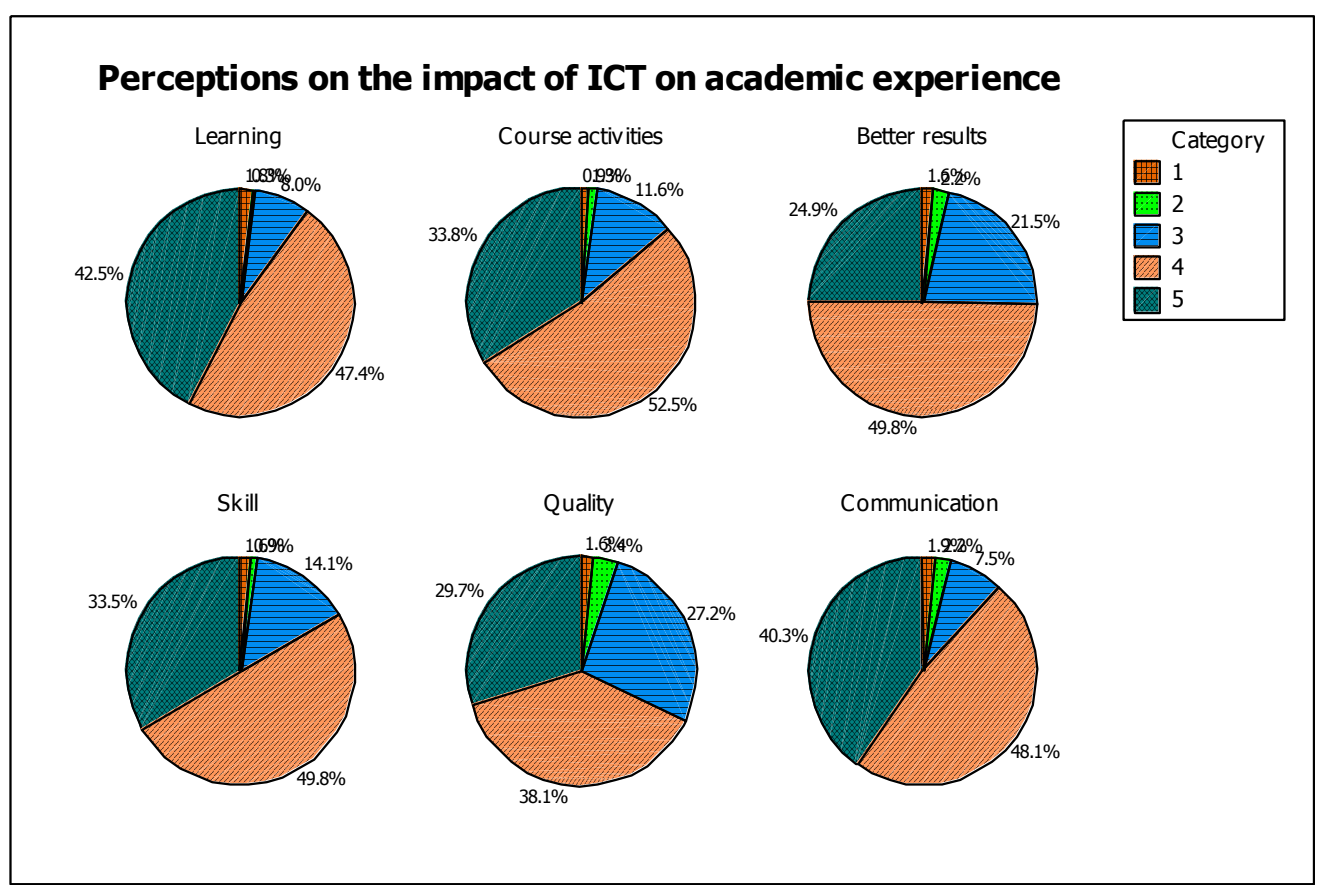

Note: 1- Strongly disagree, 2-Disagree, 3-Neutral, 4-Agree, 5-Strongly agree

Figure 2: Distribution of students' perceptions on the impact of using ICTs on academic experience 
As shown in the Figure 2, majority of the students (89.9\%) believe that using ICTs may help them to improve their learning in the university. A considerable percentage of respondents, $88.4 \%$ believe that using ICTs they can have a better communication and $86.3 \%$ believe that ICTs will make more convenient environment to perform their course activities. A higher percentage of respondents', $83.3 \%$ believe the usage of ICTs will improve their IT/information management skills in general. $67.8 \%$ of students believe that using ICT will help them to improve the quality of career as a university student. $74.7 \%$ of students believe that using ICT will help them to obtain better results in the university.

Majority of the students $(74 \%)$ perception is that Internet/E-mail is mostly useful, for improving learning, doing course activities more conveniently $(66.9 \%)$, to get better results in their subjects $(69.6 \%)$, to improve their IT/information management skills in general (75.6\%) and to improve the quality of their career as a university student $(66.7 \%)$, to make their communication activities more convenient (51.2\%). But 37.6\% of students' perception is computer will help them to improve their IT/information management skills in general and $57.4 \%$ of students' perception is mobile phones make their communication activities more convenient.

Internet/E-mail mostly useful for improving learning, doing course activities more convenient, to get better results in their subjects, to improve their IT/information management skills in general and to improve the quality of their career as a university student, and will make their communication activities more convenient.

\section{Conclusion}

Results reveal that more than $80 \%$ of freshmen have facilities to access desktop/portable computer at any time especially at their homes and that is rather higher for urban students. Most of the first year students mostly use the computer applications and they have rated that they are much more skilful on them. Most of the time IT students have gone beyond them specially on using Internet/e-mail as well as Web searching. Fantastically usage frequency and the self rated skills for all of these ICT activities are greater for the male 
students than females. Also the first years who belong to urban communities always believe that they are more skilful on ICT and using more frequently. At the same time Architecture students are in somewhat below than others in using ICTs as well as the level of ICT skills. Majority of the students believe that using ICTs may help them to improve their learning in the university. Further the study revealed that Internet/E-mail mostly useful for improving learning, doing course activities more convenient, to get better results in their subjects, to improve their IT/information management skills in general and to improve the quality of their career as a university student, and will make their communication activities more convenient as the perceptions of first year students. Majority of the female freshmen mentioned that they are willing to use ICTs to find information on academic purposes and male freshmen are willing to use ICTs to download software and other related things.

\section{Recommendations}

Freshmen who have followed introductory computer courses always rated themselves as more skilful on ICTs and they have stated that they use ICTs more frequently. Therefore it is recommended to enhance the existing introductory computer courses for first years and implement new programs in universities.

Study revealed that the usage and the skills on ICTs are below for Architecture students and it is recommended to make existing introductory computer courses compulsory and to implement new compulsory courses for them in their faculties because they should be more ICT literate to successfully face the technologically developed job market.

In order to encourage the use of ICT by freshmen, it is recommended that the duration of providing access to ICTs in libraries should be extended. The libraries need to be kept open for extra hours and Library staff should be more helpful for freshmen in using ICTs.

As the study revealed first year students who came from rural areas are somewhat reluctant to use ICTs and they have rated themselves that they are not much more skilful on ICTs. Therefore it is recommended to enhance the existing programs such as Nanasalas which have been implemented by the government to bring novel technologies for villages. 


\section{References}

Aturupane, H. (2008). Celebrating 60 years of progress and challenges in education in Sri Lanka (pp. 1-43). Westminster. Retrieved from http://www.cecomm.org.uk/images/stories/reportsconferences/Aturupane\%20paper\%20final\%20Jan\%2011\%2009\%202009.pdf

Digital Opportunity Initiative (2001). Creating a development dynamic: Final eport of the digital opportunity initiative. Accenture, Markle Foundation, UNDP.

Hoffman, M. E., \& Vance, D. R. (2005). Computer literacy: what students know and from whom they learned it. In Proceedings of the 36th SIGCSE Technical Symposium on Computer Science Education (pp. 356-360). New York, NY, USA: ACM. doi:10.1145/1047344.1047467

Madigan, E. M., Goodfellow, M., \& Stone, J. A. (2007). Gender, perceptions, and reality: technological literacy among first-year students. In Proceedings of the 38th SIGCSE Technical Symposium on Computer Science Education (pp. 410-414). New York, NY, USA: ACM. doi:10.1145/1227310.1227453

Prensky, M. (2001). Digital natives, digital immigrants part 1. On the Horizon, 9(5), 1-6. doi:10.1108/10748120110424816 